\title{
Enhancing the quality of kindergarten education in Singapore: policies and strategies in the 21st century
}

\author{
Ching Ting $\operatorname{Tan}^{*}$ (1)
}

*Correspondence:

chingtingtan@hku.hk; chingting_tan@yahoo.com

Faculty of Education, The University of Hong Kong, Pok

Fu Lam Road, Pok Fu Lam, Hong Kong

\begin{abstract}
Almost all children in Singapore complete 1 year of preschool before entering primary school. However, preschool education (PSE) is not compulsory and is provided primarily by the private sector. Taking the national agenda for reforming PSE at the start of the twenty-first century as the point of departure, this paper describes and discusses the policies and strategies that have been introduced and implemented for preschool quality enhancement in the past 15 years. Three major waves of preschool policy reviews were undertaken in 2000, 2008, and 2012 attesting to the seriousness the government attaches to improving PSE for encouraging a strong start for every child. The key recommendations of these reviews were related to uplifting teacher, center, and program quality, and enhancing the affordability and accessibility of PSE. Opportunities and challenges associated with implementing recommendations for quality enhancement are discussed and suggestions to further enhance PSE in Singapore are explored.
\end{abstract}

Keywords: Singapore, Preschool education, Policies and strategies, Curriculum reform

\section{Background}

The value of quality early childhood education and care (ECEC) in establishing a strong foundation for lifelong learning and reaping social and economic benefits is well supported by a wealth of multidisciplinary research. These long-term benefits have prompted many countries throughout the world to prioritize ECEC on their national agenda, putting in focused efforts in their pursuit of quality ECEC in the recent years. Since the turn of the twenty-first century, the Singapore government has invested substantial resources in formulating and executing policies and strategies to raise the quality of preschool education (PSE) in several high-leverage areas (Tan 2007). In 2012, the Prime Minister, Lee Hsien Loong, announced that government efforts to uplift the overall quality of PSE would be amplified by strengthening teacher training and curriculum leadership, establishing government kindergartens to catalyze quality improvements, enhancing affordability for financially disadvantaged families, and improving policy coordination and regulation of the early childhood sector by forming a new agency (MOE 2012a). Furthermore, the first government-funded large-scale longitudinal study of the impact of PSE on children's cognitive and non-cognitive outcomes commenced in 2015 (Goy 2015). Another large-scale nation-wide birth cohort study was also funded to

(c) The Author(s) 2017. This article is distributed under the terms of the Creative Commons Attribution 4.0 International License (http://creativecommons.org/licenses/by/4.0/), which permits unrestricted use, distribution, and reproduction in any medium, provided you give appropriate credit to the original author(s) and the source, provide a link to the Creative Commons license, and indicate if changes were made. 
investigate and understand the prevention and management of health problems faced by Singaporeans from pregnancy to infancy in 2008 (Growing Up With Gusto 2009). While considerable efforts have been made to promote a strong start for every child since 2000, the newly announced slew of strategies and investment in early childhood research signal strongly a compelling state interest and commitment in accelerating and boosting quality improvements in early childhood development and education in Singapore.

The main objective of this article is to provide an overview of the major policies and strategies adopted under a three-pronged approach to improve teacher, center, and program quality for kindergarten education in Singapore since 2000. Additionally, a special emphasis on the kindergarten curriculum reform is included and discussed. In this article, ECEC is used as a general term to refer to the educational and care services catered for the holistic development of children from birth to 8 years, while early childhood education (ECE) refers to educational programs for children aged 3-6 years. To be consistent with the terminologies commonly used in the context of Singapore, the author uses PSE to refer to all educational programs and services provided before formal schooling for children aged between 4 and 6 years in kindergartens and child care centers, and early childhood care and education (ECCE) for early childhood development programs and services for children below the age of 7 .

\section{The Singapore context}

Singapore is the only Chinese-dominated multi-racial and multi-cultural society in Southeast Asia. The total population of the small island nation currently stands at about 5.5 million and the ethnic groups among the 3.9 million citizens and permanent residents comprise $74.3 \%$ Chinese, 13.3\% Malays, 9.1\% Indians, and 3.2\% other ethnicities (Singapore Department of Statistics 2016). Although small in size and lacking in natural resources, Singapore has a reputation of being a successful nation-state with rapid economic growth and high efficiency, and is well regarded internationally for its world-class workforce and education system. The development and shaping of Singapore's education policy since her independence in 1965 has demonstrated that ensuring a tip-top education system is core to the country's efforts in sustaining and strengthening its viability and relevance in the global economy (Gopinathan 2007). The Singapore government invests heavily in the education sector, spending about half of its total expenditure for social development on education at approximately 3\% of the GDP each year (Singapore Department of Statistics 2016). As a result of the state's significant role in financing and reforming education, Singapore has consistently been ranked top or is among the top ranking countries in international assessments for academic achievements such as the Trends in International Mathematics and Science Study (TIMSS) and the Programme for International Student Assessment (PISA).

\section{Background information of PSE in Singapore}

All Singapore children start formal school and compulsory education at Primary 1 (P1) in January of the year they turn 7 years of age. Even though PSE is not compulsory and is not part of the official education system, the government recognizes and acknowledges that the early years are crucial for children's holistic development and should remain appropriate and adaptable to meet the developmental and learning needs of young 
children. Despite several calls for the government to mandate compulsory PSE or to make PSE a part of the public education system, the government has cautioned against these recommendations to avoid the danger of formalizing PSE too early and subjecting preschoolers to an overly structured and academic-oriented curriculum aimed merely for academic readiness (Zulkifli 2010). There is also no strong impetus to make PSE compulsory since Singapore has achieved an almost universal participation rate in PSE despite it being voluntary and fee paying. In 2012, the Ministry of Education (MOE) reported that more than $99 \%$ of Singaporean children had attended at least one year of PSE before entering primary school (Wong 2012). As such, instead of making PSE mandatory, the government is committed to target its efforts in areas which would give the greatest leverage on raising the overall quality of PSE and enhancing the affordability and accessibility for children, especially those from less advantaged homes to have a strong start by attending quality preschools. Figure 1 shows the key government decisions made on PSE in Singapore including major events that occurred before 2000.

\section{Preschool landscape}

The Singapore preschool sector comprises child care centers and kindergartens, which are the two main forms of PSE providers for children below the age of 7. Historically, child care centers and kindergartens were set up to meet different policy objectives. Started in the 1940s to provide custodial care services for children to support working mothers from low-income families, child care centers increased in number as more women joined the workforce to meet the demands of the growth of labor-intensive industries in the 1960s and 1970s (Khoo 2010). On the other hand, kindergartens were established by churches, non-profit organizations, and private entities for educational purposes in the 1940s and 1950s. Both types of preschool providers, commonly referred to as preschool centers in the Singapore context, provide a formalized 3-year preschool program in Nursery $(\mathrm{N})$ classes for 4-year-olds, kindergarten 1 (K1) classes for 5-yearolds, and kindergarten 2 (K2) classes for 6-year-olds. Kindergartens generally offer a 3- to 4-h program, whereas child care centers provide half-day, full-day, and flexi-care

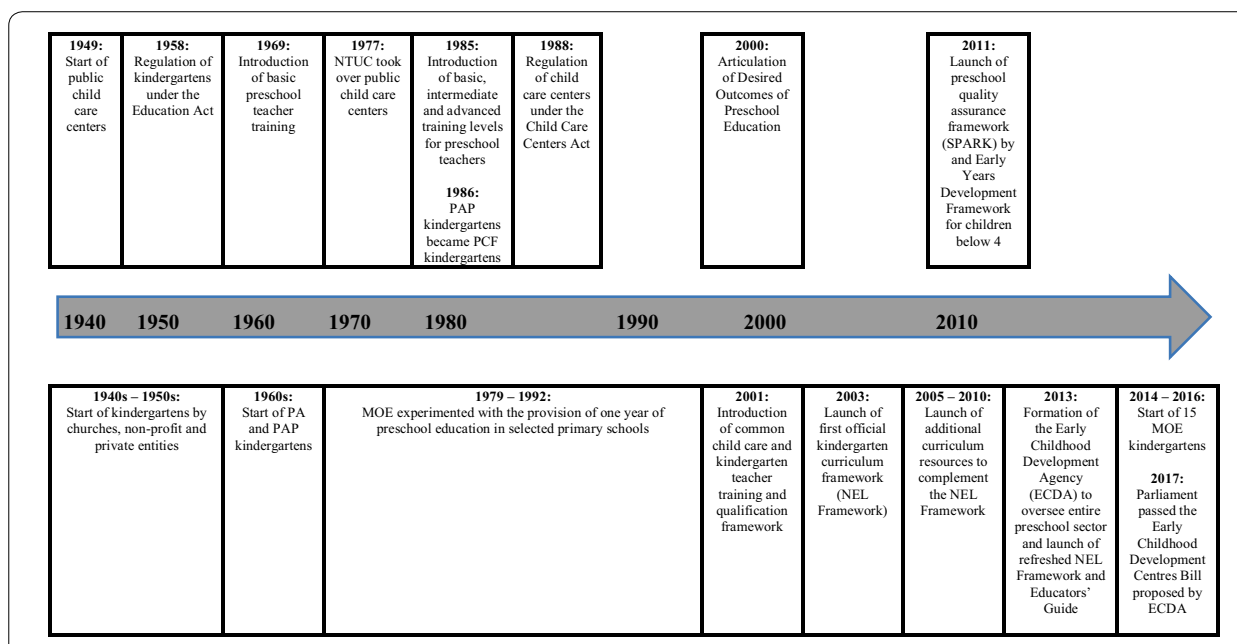

Fig. 1 Prominent milestones in Singapore's preschool sector 
programs to meet the diverse needs of working parents. Typically, children in Singapore would be enrolled in either a child care center or kindergarten before they start school at P1. According to the statistics reported by the Early Childhood Development Agency (ECDA), there are currently more than 1300 child care centers and about 480 kindergartens in Singapore.

\section{Government involvement in PSE provision}

Currently, PSE in Singapore are predominantly provided by the private sector including community foundations, religious bodies, and social and business organizations. But this was not always the case. Public child care centers which were first set up in 1949 under the Ministry of Social Affairs were eventually taken over by the non-public organization for union workers known as the National Trades Union Congress (NTUC) in 1979 (UNESCO 2007). Since then, NTUC has been the largest provider of ECCE services which operates 141 child care centers presently. In the case of kindergarten education, Singapore had experimented with an extra year of pre-primary education in the formal school system in selected primary schools between 1979 and 1993. The idea of admitting children 1 year earlier into primary schools for the Pre-Primary Programme (PPP) was mooted by the founding Prime Minister of Singapore, Lee Kuan Yew, in 1978 to facilitate the learning of both English and Chinese by children from dialect-speaking homes in those days (Ngiam 1978). In 1989, the PPP was discontinued as it was found that though beneficial, it was not cost-effective to run the program solely for early language learning especially when private kindergartens were also doing a credible job in this aspect (Lim 1989). Parents were, however, in favor of the PPP as it charged a lower fee than private kindergartens and assured them a place for their children in the primary school that offered the PPP. Following the discontinuation of the PPP, MOE proposed a 7-year primary school system consisting of a Preparatory Year Programme (PYP) in the first stage for 5-year-olds, P1 to P4 in the foundation stage, and P5 to P6 in the orientation stage in 1990 (Chua 1990). However, the pilot PYP was subsequently phased out in 1993 for better utilization of limited public funds and school resources to upgrade the formal education system (Govt to Stop Preparatory Year Classes 1992).

Subsequently, aside from playing a regulatory role, the Singapore government left provision of PSE in the hands of the private sector and adopted a light-touch approach to PSE development to allow a diverse landscape for meeting the different needs of parents. It was not until after more than three decades of non-direct intervention that Singapore announced in 2012 that it would for the first time in history establish 15 government kindergartens to provide quality and affordable K1 and K2 programs. Even though this decision may seem to be a U-turn taken by the government in the provision of PSE, it shows the government's commitment in prioritizing PSE by re-conceptualizing the provision of kindergarten education and driving curriculum leadership in the hope of catalyzing quality improvements and maintaining affordability in the preschool sector.

\section{Governance and regulation}

Prior to 2013, two ministries had historically and traditionally overseen Singapore's preschool sector. Child care centers were licensed by the Ministry of Social and Family Development (MSF), which was formerly known as the Ministry of Community 
Development, Youth and Sports (MCYS), and regulated under the Child Care Centers Act enacted in 1988. Kindergartens, on the other hand, were registered with MOE and regulated under the Education Act enforced in 1958. The division of auspices between two ministries not only created a split governance system for PSE services but also a view that 'care' and 'education' of young children are separate aspects of early childhood development. On one hand, MOE's responsibility for kindergartens focused on meeting the educational needs of children with the key priority set for enhancing quality of classroom teaching and learning. On the other hand, MCYS'/MSF's priority for child care centers focused on meeting social and family needs through improving the affordability and accessibility of custodial care services. These fundamental differences in policy aims for the two ministries resulted in policy initiatives that were developed and run in parallel, which can at times create unevenness in operational and regulatory procedures such as funding and subsidy streams, and staff training and qualification requirements for child care centers and kindergartens.

Efforts to better coordinate policies and practices at the system level between the two ministries came about with the setting up of a Pre-school Education Steering Committee in 1999 led by MOE and included members from the two ministries to study ways of improving the preschool sector as a whole. Under the recommendation of the Steering Committee, kindergarten programs for children aged 4-6 years in child care centers and kindergartens are now guided by a common set of teaching guidelines and learning goals spelled out in a curriculum framework developed by MOE since 2003. Principals and teachers teaching kindergarten levels in both child care centers and kindergartens also share the same entry requirements for academic and professional qualifications and training path for professional upgrading since 2001. In addition, a common quality assurance framework was implemented by MOE in 2011 to evaluate and endorse the quality of preschool programs in child care centers and kindergartens. In these respects, Singapore has made more progress than many countries with a split and parallel ECEC governance system. For instance, although Korea has recently developed and implemented a common curriculum across all ECEC settings for children aged 3-5 years starting in 2013, teacher education and quality assurance systems are still separately operated and regulated for the child care and kindergarten sectors (Kaga et al. 2012).

The fragmentation and inefficiencies of ECEC services as a result of incoherent objectives, policies, and practices from a split governance system hinder the delivery of quality goals for ECEC (Bennett 2008; Eurydice 2009; Organisation for Economic Co-operation and Development [OECD] 2006, 2012). The emerging trend is thus for countries to move towards an integrated system for care and education services either under a single ministry or an autonomous agency to achieve better governance (OECD 2015). Unlike most countries in the OECD which have typically assigned the entire ECEC sector under the education ministry, Singapore set up a new agency known as the Early Childhood Development Agency (ECDA) that brings together relevant people and resources from the two ministries to integrate and regulate early childhood services across the preschool sector in 2013. Jointly supervised by MSF and MOE, ECDA is administered under MSF and centrally oversees and develops policies and practices of child care and kindergarten programs for children below the age of 7 . In order to further unify child care centers 
and kindergartens, all preschool centers will be regulated under ECDA's newly approved Early Childhood Development Centres Act which is targeted to take effect in 2018.

Based on an analysis of various integrating models by Kaga et al. (2012), establishing a new central agency to oversee the ECEC sector could potentially lead to more consistency and better quality of care and education services across the sector. However, the notion of ECEC integration entails more than a structural change of reorganizing a system that is split to one that is integrated, but rather it is critical that integration is also accomplished conceptually (Bennett and Kaga 2010). What this means for Singapore is that the success of harmonizing ECCE depends not only on how regulatory and support mechanisms across the early childhood sector are centrally coordinated and implemented under a single agency. Successfully integrating ECCE services also depends on how the amalgamation of capabilities and resources from the two ministries are best optimized to think and operate beyond the differential between child care and kindergarten programs, which has by tradition been associated with 'care' and 'education, respectively. It is thus essential to pay attention to how efforts are being made through ECDA to promote a conceptual integration of both care and education aspects in early childhood development.

\section{Key policies and strategies to enhance quality of PSE since $\mathbf{2 0 0 0}$}

The Singapore Government has stepped up its efforts in uplifting the overall quality of PSE. Over the past 15 years, Singapore has conducted three major reviews of PSE resulting in key recommendations concentrating on enhancing the quality, affordability, and accessibility of PSE, which were announced in 2000, 2008, and 2012. As a result of government's greater involvement in taking oversight of PSE, the Singapore PSE landscape has evolved significantly. This section examines the salient features of the systems and structures put in place under the waves of PSE policy reforms introduced from 2000 to enhance teacher, center, and program quality for children between the age of 4 and 6 years.

\section{Improving teacher quality}

Even though PSE was well established in Singapore by the 1960s, it was not until 1969 when basic and systematic in-service training was provided for preschool teachers by public institutions (Sharpe 1998). In 1977, the responsibility of preschool teacher training was taken over by the nation's teacher-training institution and was eventually complemented by other private training providers by the 1990s. By 1998, there were three levels of nationally accredited training courses for both child care and kindergarten teachers which were the 120 -h basic course, 210 -h certificate in preschool teaching intermediate course, and 120-h certificate in preschool management and administration advanced course (Sharpe 1998). Nevertheless, many preschool teachers remained untrained due to the limited yearly intakes of trainees by the training providers. To deal with the shortage of well-trained and qualified personnel in the preschool sector, a 3-year full-time diploma course in ECE was first launched in Ngee Ann Polytechnic, a public post-secondary education institution, in 1999.

Recognizing that teacher quality is a key lever in delivering high-quality early years education, the government introduced a new framework for preschool teacher training 
which mapped out a common training pathway for child care center and kindergarten leaders and teachers of kindergarten age children in 2001. For the first time, the government mandated the minimum entry requirements for preschool leadership and teaching. The new teacher-training framework required all incumbent preschool leaders to obtain their teaching and leadership diplomas by January 2006, and teachers to be certificate-trained, as well as centers to have one diploma-trained teacher in every four teachers by January 2008. In order to support major non-profit kindergarten operators to meet the stipulated staff qualification requirements, a yearly recurrent government grant was introduced for eligible kindergartens to provide better salary schemes and other supporting resources to attract and retain better-qualified professional staff. Subsequent to the advent of the new teacher training and qualification requirements, private training providers mushroomed from four in 1994 to eight in 2000 and 23 in 2004, to meet the sudden surge in training demands. Within a span of 6 years, there was an increase in certificate- and diploma-trained teachers from an estimated 31\% in 2000 to $82 \%$ by March 2007 and an increase in the qualification of principals from 14\% who were diploma-trained to $70 \%$ (Zulkifli 2007).

Having made significant progress in strengthening preschool staff training and qualifications after the introduction of the training framework, the minimum entry standards into kindergarten-level teaching were further boosted in 2008 to enhance the quality and preparation of teachers. The minimum qualifications required for new entrants were raised from three to five passes in the end-of-secondary school national examination, and from a certificate level to a diploma level for teaching. In order to teach K1 and $\mathrm{K} 2$ classes or children aged 5-6 years, certificate-trained incumbent teachers must upgrade to the diploma level by January 2013. At the same time, each center should have at least $75 \%$ of all its teachers meeting the new requirements for academic and professional qualifications. As a result of raising the entry bar to promote teacher quality, the proportion of diploma-trained teachers or those undergoing diploma training saw an increase from 58 to $85.5 \%$ for kindergarten teachers and 46 to $70 \%$ for child care teachers between 2006 and 2010 (Zulkifli 2011). By March 2012, the percentage of diplomatrained preschool teachers and trainees rose further to about $90 \%$ (Wong 2012). At the center level, $77.4 \%$ of kindergartens and $69.6 \%$ of child care centers had already achieved the stipulated requirements for teachers' academic and professional qualifications by the end of 2010, as compared to a base of less than $20 \%$ of preschool centers in 2006 (Zulkifli 2011). It is however, worthy to note that while the significant rise in numbers of bettertrained teachers seems impressive, it is still unclear whether and how this improvement has impacted on the overall quality of classroom teaching practices and children's developmental outcomes. This is an area of concern especially given the decentralization of preschool teacher training and the potential differences in the quality and rigor of fulltime and part-time training programs offered mainly by private training providers.

Unlike teachers teaching in primary and secondary schools who are trained by the national teacher-training institute in Singapore, training of preschool teachers is conducted mainly by private training agencies and a few polytechnics or government postsecondary education institutions. To oversee quality standards and consistency in the training programs provided by the various training providers, a Pre-school Qualification Accreditation Committee (PQAC) was jointly set up and steered by MOE and MCYS in 
2001 to assess and approve the course content, modes of assessment, trainer qualifications, training facilities, and resources for teacher-training programs up to the diploma level. The PQAC served as a gatekeeper of teacher preparation programs by reviewing and raising accreditation standards to ensure that the training programs stayed rigorous and up to date with new developments in the ECCE field between 2001 and 2013. The PQAC was dissolved with the formation of ECDA, and presently, all ECCE training programs are approved by ECDA and are conducted by eight private training agencies and four government post-secondary education institutions, which include three polytechnics. Three full-time 3-year diploma programs in the field of ECE are currently offered and conducted by two polytechnics to equip fresh school leavers with the necessary knowledge, skills and attitudes to become competent early childhood educators. These two polytechnics also conduct a part-time teaching diploma course for existing and new teachers and they are the only institutions that offer the part-time 850-h advanced diploma in early childhood leadership (ADECL) course starting from April 2016 to prepare existing senior teachers nominated by their employers for leadership roles. With effect from October 2014, all ECCE courses conducted by private training agencies must be accredited by the Workforce Development Agency (WDA) in Singapore under the workforce skills qualifications system (WSQ).

To further improve the caliber of the teacher pool in the preschool sector, MOE put in place an accelerated conversion diploma course in 2009 to attract and prepare midcareer entrants and fresh university graduates with the competencies and skills to teach kindergarten children. Additionally, teachers and principals are also encouraged to pursue diploma and degree courses in ECCE through scholarships, teaching awards and bursaries offered by the government to further practitioners' knowledge in curriculum, pedagogy, leadership, and management. In 2013 and 2015, further enhancing strategies to increase quality of early childhood educators were announced by ECDA which included outlining a professional development roadmap, mounting core and milestone courses, providing cash incentives and recognition at key training milestones attained, supporting enhanced internships for student teachers, and establishing a professional upgrading program to grow and advance careers of experienced and potentially good educators. To build a professional network in the early childhood sector, 14 early childhood leaders with deep leadership and professional expertise were identified and appointed to serve as role models for promoting teacher professional development and curriculum leadership in 2015.

Better quality staff comes with a price. Therefore, to help keep affordability of PSE, the government has been providing annual funding under the anchor operator (AOP) scheme for eligible kindergartens and child care centers since 2009 to support the preschool centers in attracting and retaining better quality teachers. Despite these efforts, the manpower situation in the preschool sector remains tight especially with the increasing demand for quality staff and ECCE services in the recent years. Employers also face quality staff recruitment and retention challenges due to the inadequate salary scales and limited career prospects for diploma and degree holders in the preschool industry. As the government works towards building a more professional and qualified preschool workforce, supporting measures to facilitate an adequate supply of qualified 
teachers and a competitive remuneration structure for the preschool sector deserve further examination and strengthening.

\section{Improving center quality}

Systems and structures were also put in place at the center level to encourage kindergartens to work towards self-monitoring for continuous improvement in their program and processes. In 2003, MOE developed and introduced a self-evaluation tool called 'Pursuing Excellence at Kindergartens' or PEAK for kindergartens which became the precursor of the quality rating scale (QRS) developed for the quality assurance system known as the Singapore Pre-school Accreditation Framework or SPARK launched in 2011. SPARK enables preschool centers to undergo an external evaluation of their strengths and areas for improvements and endorsement of center quality. Assessment and certification under SPARK are based on the quality benchmarks provided in the QRS in the areas of leadership, planning and administration, staff management, resources, curriculum, pedagogy, as well as health, hygiene, and safety. While the QRS is a contextually appropriate instrument developed by content experts in the MOE with due recognition given to the curriculum and pedagogical guidelines spelled out in the official kindergarten curriculum framework, it has been validated against three well-established instruments. These instruments are the Early Childhood Environment Rating Scale-Revised (ECERS-R) (Harms et al. 2005), the Early Childhood Environment Rating Scale-Extension (ECERSE) (Sylva et al. 2003), and the Program Administration Scale (PAS) (Talan and Bloom 2004). Each SPARK certification is valid for three years and all SPARK-certified centers are required to conduct an annual self-appraisal exercise using the QRS and to draw up a yearly action plan to ensure systematic and sustainable efforts for continual improvements. Despite being a voluntary framework, it is encouraging to note that one in three preschool centers is SPARK-certified across the island as at September 2016 (MSF 2016).

Although the government had previously experimented with the provision of a 1-year pre-primary class within primary schools between the late 70s and early 90s, 2014 was the watershed year as it marked a prominent milestone in the evolutionary journey of the Singapore preschool landscape with the establishment of the first five MOE-run kindergartens. Set up in response to a growing demand for high-quality kindergarten education, the former Education Minister, Heng Swee Keat, who was also the co-Chair for the inter-ministerial MOE-MSF Implementation Committee for Enhancing PSE outlined plans for the establishment of 15 MOE kindergartens between 2014 and 2016. The sites of these 15 public kindergartens appeared to be carefully selected within community spaces and primary schools located in the suburban towns where most families live in public flats in order to better reach out to children from middle and lower income families. The MOE kindergartens are intended to (1) provide quality PSE that is affordable to Singaporeans, (2) pilot teaching and learning resources developed by MOE specialists for sharing with the preschool sector, and (3) work with other preschool operators to distill and share good practices that are scalable, suitable, and sustainable for the Singaporean context (Heng 2013). MOE reported that as of April 2016, there is a total enrollment of about 1700 children in the 15 government kindergartens (Puthucheary 2016). MOE is tracking the inaugural batch of $267 \mathrm{~K} 2$ children who have moved on to P1 in January 2016. The development and learning of the children from MOE kindergartens 
is also being assessed and monitored under an ongoing large-scale longitudinal research study of the impact of PSE on children's learning outcomes (Teng 2015). Since its inception three years ago, a growth in demand and enrollment in the MOE kindergartens has been reported (Davie 2017) and MOE has received positive feedback from parents that their children enjoyed learning at the MOE kindergartens and were more independent, expressive, and confident with good social skills that helped them to adapt well in primary schools (Ng 2016; Puthucheary 2016). Other than adding a new PSE option to the parents, there has been no great observable impact created by the nation's nascent public preschool industry since the sector remains primarily privatized with the preservation of a variegated curricular and pedagogical landscape. MOE has made no indication thus far on the future and long-term development plans for these public kindergartens, except for the recent announcement that an additional three centers would be set up in 2018 in neighborhoods with young families. It is postulated that until more conclusive evidence is gathered from a proper evaluation of the impact and experience of the MOE kindergartens, it seems too early to predict how the government's direct involvement in running kindergartens will eventually transform the overall quality of children's preschool experiences and Singapore's preschool ecology.

\section{Improving program quality}

The MOE first launched a curriculum framework in January 2003, which was refreshed in 2012 to promote consistent quality standards in the delivery of kindergarten programs across the sector. The framework is the first official curriculum document specifying the nation's desired best practices for kindergarten teaching and learning as well as the aspirations for a PSE that emphasizes holistic development of children instead of academic readiness. As with most official ECE curriculum documents issued globally, Singapore's kindergarten curriculum framework, known as Nurturing Early Learners: A Framework for A Kindergarten Curriculum in Singapore or the NEL Framework, is nonprescriptive but spells out broad principles and guidelines for curriculum and pedagogy targeted at children aged 4 to 6 years. Following the dissemination of the NEL Framework, additional curriculum resources were further developed and published by MOE to support early childhood educators in translating and putting the framework into practice more effectively. These resources included teaching guidelines for the three official Mother Tongue Languages (MTLs), namely Chinese, Malay, and Tamil between 2005 and 2006, a curriculum guide with practical teaching strategies to complement the NEL Framework in 2008, and a curriculum resource package to support nurturing of learning dispositions in 2010 and 2011. The NEL Framework together with an educators' guide, a set of teaching and learning resources, as well as a parallel set of resources for the three official MTLs now form a comprehensive set of curriculum resources to strengthen the design and delivery of a quality kindergarten program. To ensure a continuity of quality standards in the care, development, and learning experiences of children from infancy through the kindergarten years, MSF introduced the Early Years Development Framework (EYDF) to complement the NEL Framework in 2011 to guide quality care and learning practices for children below 4 years in child care settings. Consistent with the NEL Framework, the EYDF emphasizes an intentional and developmental approach to supporting children's holistic development and learning. 
On the whole, consolidated government efforts adopted under the policy framework forged by Singapore since the turn of the new millennium reflect the government's zeal for high-quality ECCE by perpetually seeking workable practices to strengthen the PSE system. In striving to fine-tune the PSE policy agenda, the past waves of policy reviews and recommendations have helped to elevate the baseline quality of the preschool sector in many ways. The laissez-faire attitude previously adopted for the sector has transformed into a systematic approach towards regulating teacher and leadership requirements, promoting and sustaining center-level quality standards, and directing the development and delivery of a good quality and appropriate curriculum and program.

\section{The kindergarten curriculum reform}

Since becoming an independent state in 1965, meritocracy has been a core principle governing Singapore which allows Singaporeans, regardless of who they are, to be recognized and rewarded according to their ability and achievement. As a result, many parents have high academic expectations for their children and take great pains to ensure that their children are adequately prepared in the early years for academic readiness and future school success. Over the years, this mentality has resulted in a highly competitive and stressful education system and many preschool centers thus put children through a drill and practice approach for the development of literacy and numeracy concepts and skills. Arising from a major review led by MOE under the Steering Committee on PSE, MOE announced in 2000, its commitment to re-direct the focus of PSE onto the crucial aspects of kindergarten education as it was far more important to nurture children's eagerness to learn and their sense of wonder and curiosity in the preschool years (Wong 2000). This marked the beginning of the nation's efforts in reforming the kindergarten curriculum with the overall aim "to emphasize that PSE should be about preparing children for lifelong learning, not just a preparation for P1" (Wong 2000, para. 6).

\section{Desired and key stage outcomes of PSE}

The first step taken was to define and articulate MOE's end goals for PSE. Formulated in consultation with professionals and practitioners in ECE and policy makers, eight Desired Outcomes of Pre-school Education were presented in 2000. These outcomes, which had deliberately de-emphasized academic learning and achievement, delineated the values, dispositions, and skills needed for the total development of a child and lifelong learning. The desired outcomes of PSE were updated in 2013 and are now known as the Key Stage Outcomes of Pre-school Education (see Tabe 1) which aim to lay a strong foundation for children to become confident individuals, self-directed learners, active contributors, and concerned citizens so as to achieve the overarching desired outcomes of Singapore's education system.

\section{A curriculum framework for kindergartens}

The development of a national curriculum framework with clearly defined learning goals and standards was identified as one of the five key levers for encouraging quality of ECEC in OECD countries (OECD 2012). In the recent years, OECD countries such as Australia in 2009, England in 2014, Sweden in 2011, Ireland in 2009, and Korea in 2011 have either introduced or updated their national early years curriculum or learning framework with 
defined key learning goals and broad pedagogical principles as part of their government's reform agenda for ECEC (OECD 2012). A similar trend is also observed in other countries and regions in the East Asian and Southeast Asian parts of the world such as mainland China in 2012, Hong Kong in 2017, Malaysia in 2010 and Singapore in 2013 in which broad curriculum guidelines have been updated and re-issued.

Unlike mainstream schools, child care centers and kindergartens in Singapore do not have a centralized curriculum or standardized syllabus prescribing the contents to be taught. Preschool centers are thus free to adopt and implement a curriculum and the pedagogies that best meet the center's educational philosophy and cater to the different preferences of parents and needs of the children. As a result, the preschool landscape in Singapore offers a diversified range of curriculum approaches that contributes to an uneven level of program content and teaching standards across the sector. In order to promote more evenness in the quality of teaching and learning across preschool settings, the second step taken by Singapore in its efforts to reform kindergarten education was to develop a curriculum framework outlining broad teaching and learning principles and strategies for the holistic development of children. In January 2003, Singapore witnessed the laying of a prominent milestone in the journey of improving kindergarten curriculum and pedagogy by launching the NEL Framework. While the NEL Framework is not mandatory, it signifies the first official document or "nationally endorsed curriculum for children in preschools" as described by Ang (2006, p. 205) that made explicit the nation's aspirations and directions for a quality and appropriate kindergarten program. The $N E L$ Framework aims to lay a sound foundation for early learning based on internationally accepted principles and research findings of ECE. In a nutshell, the curriculum framework is underpinned by six key guiding principles which advocate learning through an integrated approach, play, and interactions with the support from teachers in six learning areas for the holistic development of children. Teachers were also encouraged to restructure the learning environment by setting up learning centers in the classroom to minimize passive learning and maximize opportunities for active and interactive learning.

Efforts to ensure the provision of quality learning experiences for preschool children continued after the launch of the NEL Framework. In 2008, to better support preschool practitioners in operationalizing the framework, the MOE produced and provided each kindergarten teacher with a practical curriculum guide that illustrated in greater detail a curriculum planning process and included samples of learning activities and suggestions for children's development and learning at the N, K1, and K2 levels. The curriculum guide stressed the professional role teachers played in supporting children's learning and development, and encouraged them to engage in reflective practice as they apply the six principles espoused in the NEL Framework which is encapsulated in the acronym, 'iTeach' (Pre-school Education Branch 2008). The 'iTeach' principles stand for (1) integrated learning, (2) teachers as supporters of learning, (3) engaging children in learning through play, (4) ample opportunities for interactions, (5) children as active learners, and (6) holistic development. One key element of the curriculum guide was to emphasize the value of purposeful play or play experiences that should be provided for children to learn meaningfully with the support and guidance from teachers by clarifying and distinguishing between child-directed and teacher-directed play. 
The NEL Framework was refreshed in 2012 by taking into account current educational and research developments as well as feedback from early childhood educators and professional advice from ECE consultants and specialists. Currently called Nurturing Early Learners: A Curriculum Framework for Kindergartens in Singapore, the updated framework maintains its broad parameters and universal guidelines for a child-centered and holistic approach to ECE, except this time it states clearly MOE's belief of how children learn and the learning outcomes of kindergarten education to better manage parents' and educators' expectations of PSE. The refreshed version of the NEL Framework is supplemented with seven volumes that make up an educators' guide. The NEL Educators' Guide, published in 2013, builds and elaborates on the pedagogical principles and practices recommended in the NEL Framework. An overview of the salient features of the refreshed NEL Framework is outlined in Table 1.

\section{Opportunities and issues related to the curriculum reform}

The launch of the nationally endorsed NEL Framework clearly reflects MOE's intent to shift the nation's preschool orientation from a didactic and academic approach to one that is less instructional but more interactive and play-based with the long-term objective of nurturing children as lifelong learners. It calls for less emphasis on formal teaching of arithmetic, reading, and writing skills and more opportunities for children to inquire, explore, and discover the world around them while developing their social and emotional skills, and positive learning dispositions through a child-centered and playbased curriculum (MOE 2012b; Pre-school Education Branch 2008; Pre-school Education Unit 2003). The nation's desire to re-shape the preschool teaching and learning landscape is evident in the words of two former ministers of education:

"We should not be preparing children in the preschool years for primary school, by anticipating and prefiguring the primary school curriculum. The preschool years are crucial in themselves (Shanmugaratnam 2003, para. 7)."

"We must therefore start right, and start young. A good preschool education, especially in the kindergarten years, provides the foundation for learning. Rather than 'schoolify' preschool, we must focus on what would be relevant to teach at that stage. Education is a lifelong journey, not a short sprint. Preschools should use play to stimulate the learning of languages and social-emotional skills. It should be purposeful and fun, invoke a sense of curiosity and seed a love for learning (Heng 2012, para. 18)."

In order to steer preschool centers away from providing a didactic and skills-based program, the NEL Framework promotes a thematic and integrated approach to learning instead of a compartmentalized or subject-based learning approach. Centering on the child, the framework encourages teachers to be facilitators in children's learning process by taking into account children's developmental and learning needs as well as their interests and abilities. In facilitating and scaffolding children's learning and development, teachers are to plan appropriate learning experiences and organize the learning environment for children to acquire the necessary knowledge, skills, and dispositions, engage children in authentic learning through purposeful play and quality interactions, 


\section{Table 1 Key features of the kindergarten curriculum framework in Singapore (MOE 2012b)}

Key stage outcomes of PSE

At the end of kindergarten education, children should

(1) Know what is right and what is wrong

(2) Be willing to share and take turns with others

(3) Be able to relate to others

(4) Be curious and able to explore

(5) Be able to listen and speak with understanding

(6) Be comfortable and happy with themselves

(7) Have developed physical co-ordination and healthy habits, participate in and enjoy a variety of arts experiences

(8) Love their families, friends, teachers and school

Belief

Children are curious, active and competent learners

iTeach principles

(1) Integrated approach to learning

(2) Teachers as facilitators of learning

(3) Engaging children in learning through purposeful play

(4) Authentic learning through quality interactions

(5) Children as constructors of knowledge

(6) Holistic development

Putting iTeach principles into practice

Plan to nurture children's holistic development

Facilitate the learning process

Observe and assess children's learning

Reflect on and enhance professional practice

Collaborate with families and the community

Learning areas and learning goals

(1) Aesthetics and Creative Expression

Enjoy art and music and movement activities

Express ideas and feelings through art and music and movement

Create art and music and movement using experimentation and imagination

Share ideas and feelings about art and music and movement

(2) Discovery of the World

Show an interest in the world they live in

Find out why things happen and how things work through simple investigations

Develop a positive attitude towards the world around them

(3) Language and Literacy

Listen for information and enjoyment

Speak to convey meaning and communicate with others

Read with understanding and for enjoyment

Use drawing, mark making, symbols and writing with invented and conventional spelling to communicate ideas and information

(4) Motor Skills Development

Enjoy through participation in a variety of physical activities

Demonstrate control, coordination and balance in gross motor tasks

Demonstrate control and coordination in fine motor tasks

Develop healthy habits and safety awareness at home, in school and at public places

(5) Numeracy

Recognise and use simple relationships and patterns

Use numbers in daily experiences

Recognise and use basic shapes and simple spatial concepts in daily experiences 
Table 1 continued

(6) Social and Emotional Development
Develop an awareness of personal identity
Manage their own emotions and behaviours
Show respect for diversity
Communicate, interact and build relationships with others
Take responsibility for their actions
Learning dispositions
(1) Perseverance
(2) Reflectiveness
(3) Appreciation
(4) Inventiveness
(5) Sense of wonder and curiosity
(6) Engagement

make observations for evaluation of children's progress in learning and development, reflect on their practice and tap professional learning opportunities to hone their pedagogical skills, and collaborate with families and the community to harness their expertise and resources to support their teaching and children's learning (MOE 2012b). It is evident that the critical role teachers play in planning, implementing, observing, evaluating, improving, and enriching the early childhood curriculum for children's learning and development is stressed upon in the NEL Framework.

While the introduction of the centralized curriculum increases opportunities for shifting towards a more holistic and less academic PSE, the recommended changes, however, require teachers to re-evaluate their understandings of early learners and rethink their approach to teaching and learning, and parents to adjust their academic expectations of preschool children. Resistance is inevitable in any change. This is especially pertinent in the case of Singapore when teachers are required to change their teaching habit of being knowledge dispensers to facilitators in children's learning process. It has been noted that government authorities in many East Asian and Southeast Asian countries and regions such as mainland China, Hong Kong, Japan, and Korea have promoted a curriculum that is primarily informed by educational philosophies and best practices drawn from Western cultures or English-speaking countries (Grieshaber 2016; Kwon 2004; Pan and Liu 2008; Rao et al. 2010). But concerns have been raised regarding the cultural conflicts arising from the importation of Western curriculum approaches and pedagogical practices into Asian contexts due to the incompatibility of the educational ideologies and cultural norms embedded in the two dissimilar Western and Eastern traditions and contexts (Hsieh 2004; Lee and Tseng 2008; Li et al. 2011; McMullen et al. 2005). In a similar fashion, the influence of Western philosophies and theories on how children learn and should be taught in Singapore's NEL Framework has been claimed to run counter to the traditional cultural beliefs and the inherent curriculum priorities held by teachers and parents in a largely Chinese society with Confucius influence (Ang 2006, 2014; Lim-Ratnam 2013; Lim and Torr 2008). There is thus a concern that efforts to downplay a formal and academically focused kindergarten curriculum are at odds with the premium value Singaporean parents placed on academic achievement and their expectations of their children to be well prepared for primary school in order to meet the demands of a highly 
competitive formal education system (Ang 2006, 2014; Ebbeck and Chan 2011; Nyland and $\mathrm{Ng}$ 2016). Moreover, as the relationship between play and learning is not always apparent, parents and even preschool educators are not fully convinced on the educational value of a play-based approach to learning. In an interview survey of 40 Singaporean parents, Ebbeck and Gokhale (2004) found that many parents sent their children for private tuition in their final preschool year as they were not confident that a curriculum adopting an informal, interactive format of teaching and learning would adequately prepare their children for formal schooling.

Despite making efforts in promoting and explaining the benefits of a less structured and academically focused curriculum by the preschool educators, parental demands for a more structured and academic approach to learning continued to have a significant influence on the type of curriculum implemented by the preschools (Ebbeck and Chan 2011). Li et al. (2012) found that teacher-directed and explicit instruction was still predominantly used in Singapore preschool classrooms to teach Chinese, suggesting minimal changes in the teaching practice. In order to foster parents' understanding of what constitutes quality and appropriate PSE, the MOE published a guide for parents to communicate and clarify the goals and objectives of the NEL Framework in 2012. In addition, concerted efforts have also been made by the MOE, ECDA, and other agencies in organizing or supporting seminars and forums for parents to learn more about holistic development of children and ways to nurture children as lifelong learners. Nevertheless, even if the intentions and aspirations for PSE held by MOE have been clearly made known to the public, the question that remains is whether these efforts are embraced by the broader community and have been impactful in preventing preschool teachers from over-teaching and parents from over-preparing their children for primary school. But as long as parents continue to perceive a rift between the intended expectations for joyful and playful learning in PSE and the realities of an academic knowledge and skillsbased learning approach in primary school education, the expectations for preschool children to be academically prepared will persist. Furthermore, Burgess and Fleet (2009) cautioned that curriculum innovations promoted through a non-mandatory document might not be implemented as the daily mundane issues and habitual practices occurring in the classroom teachers may overwhelm teachers.

It is worthy to note that while the core of the NEL Framework is the child and learning through play is one of its salient elements, the framework, however, stresses the importance of teachers' role in intentionally planning and guiding children's play to meet learning objectives for achieving desired learning goals. Therefore, instead of adopting the Western conception of play in the form of child-directed or unstructured and freechoice play, which is often deemed as a characteristic of child-centered approaches to ECE, Singapore preschool teachers are encouraged to engage children in 'purposeful play.' The NEL Framework states that:

"In purposeful play, the teacher intentionally plans the play experiences and organizes the environment to enhance the learning of children. At the same time, children are given the flexibility to explore the materials and initiate play within what the teacher has provided. While children are playing, teachers observe them to find out what they have learnt and then facilitate to reinforce or extend their learning towards meeting the intended objectives." (MOE 2012b, p. 35) 
This more intentional and purposeful approach towards children's play has been criticized by some early childhood professionals to threaten the true value of children's play. The term 'purposeful play' has also been regarded by some play advocates to be an oxymoron as one of the properties of play is clearly purposeless or with no external goals (Brown and Vaughan 2009). According to Wood and Attfield (2005), play is often described as something that is fun, free, and spontaneous and can be regarded as "deeply serious and purposeful" and "characterised with high levels of motivation, creativity and learning," or "trivial and purposeless" (p. 2). Drawing from the discourse in the NEL curriculum documents about purposeful play, the intent is for teachers to integrate a form of play that is in the midst of "the continuum of play which ranges from child-directed play (unstructured with free choice by children and with no/little support from teachers) to teacher-directed play (highly structured with only teacher-led instructions and directions)" (MOE 2013, p. 53). In other words, purposeful play is characterized by being both teacher- and child-directed.

The promotion of a similar approach towards children's play is also found in Australia's first national early years learning framework, published in 2009 (Grieshaber 2010, 2016) and England's statutory framework for the early years foundation stage which requires that "each area of learning and development must be implemented through planned, purposeful play and through a mix of adult-led and child-initiated activity" (Department for Education 2014, p. 9). Unlike the challenges faced by Australian teachers who have historically and traditionally believed in child-initiated free play without teacher involvement, teachers in Singapore are either struggling to introduce play into their classroom practice or trying not to be overly directive and restrictive in encouraging children's initiated play. The notion of purposeful play or teacher-supported play-based learning in the NEL Framework supports Tzuo's (2007) clarification that "teacher's role in guiding children's learning is not eliminated in a child-centered curriculum" (p. 33) and Dockett's (2011) appeal for a reconceptualization of play "to move away from romantic and nostalgic notions of play" (p. 42). The crux of the difficulties faced by Singapore kindergarten teachers is in striking a fine balance on the play continuum in order to best manifest teacher control and children's freedom without compromising on the enjoyment and educational value of the play experience. But as long as what this balanced form of play looks like in the classroom is not concretely illustrated and how one achieves the balance is not supported through teacher education and development, these two questions continue to challenge the way teachers interpret and enact purposeful play as accorded in the NEL Framework.

In a critical review of the original version of the NEL Framework published in 2003, Ang (2006) pointed out that "there is a clear emphasis on learning, and the framework reflects an attempt to focus on the context and process of learning, with suggestions for appropriate forms of provision" (p. 207). Lim (2004) also noted that the NEL Framework assumes that "there is a broad range of knowledge and skills that children ought to learn" (p. 398). Indeed, the newly revised framework seems to have an added emphasis on learning by defining a set of learning goals to clarify the end point expectations of PSE to help ease children's transition into primary school (MOE 2012b). While the learning goals are in turn translated into a specific set of knowledge, skills, and dispositions for each learning area, $\mathrm{MOE}$ clarified that the purpose of the learning goals was not to bring 
down the P1 curriculum demands into PSE but to build in children a strong foundation in pre-academic skills to help them access the P1 curriculum (Channel NewsAsia 2014). Interestingly, Lim-Ratnam (2013) pointed out that this justification by the MOE seems to reflect the policymakers' reluctance in letting go of "academic learning so as to convince parents and practitioners of the academic benefits of a curriculum that focuses on holistic development" (p. 420).

The effort of policymakers and education officers in advancing for a more interactive and less academic PSE in Singapore through the publication of the NEL Framework and other supporting curriculum documents is commendable. The government is hopeful that with the dissemination of a centralized set of curriculum guidelines and better teacher preparation and education, preschool teachers in Singapore would be equipped with a guidance tool, and the necessary knowledge and skills to design and deliver a quality kindergarten curriculum. However, initiating change across a diverse ECE system is a complex process. Having good intentions to change classroom practices and reflecting these intentions in curriculum documents are not enough to accomplish a transformation of ECE (Fullan 2007). According to Fullan (2007), teachers are the key change agents in education and their beliefs can facilitate or impede an educational reform. Fullan further explained that the process of implementing an educational reform is further made complex by the perspectives and experiences of individuals in the context of the country's wider educational landscape and the influences from the broader social, political, and economic forces.

Despite being inconclusive, extant literature suggests that teachers' beliefs are integral aspects of the teaching process and have a significant influence on teachers' instructional decisions and actions that ultimately impact upon children's learning and development (Clark and Peterson 1986; Pajares 1992; Spodek 1988). Several studies have shown that early childhood teachers' beliefs were important predictors of their classroom practices (Bryant et al. 1991; Hu et al. 2017; McMullen 1999; Maxwell et al. 2001; Mohamed and Al-Qaryouti 2016). In view that the NEL Framework is largely still left to the intuition and interpretation of preschool leaders and teachers in creating and enacting their own center-based curriculum, it is worthwhile to investigate what preschool teachers in Singapore believe and do in ECE and whether those beliefs and practices are congruent with the objectives of the kindergarten curriculum reform. Such research not only generates an evidence base for the state of implementation and impact of the kindergarten curriculum reform but also contributes to an empirical ground for critiquing and refining the NEL Framework. But in reality, Singapore preschool teachers' teaching beliefs and practices are understudied and less is known about the nation's current state of kindergarten curriculum reform.

In the context of globalization and a keenness to learn from other nations, signs of policy and practice borrowing and adaptation are evident in Singapore's journey to reform the kindergarten curriculum. For instance, ongoing discourses of effective practices for ECE in the international arena are steering early years curriculum and pedagogy towards a child-centered and developmentally appropriate approach with learning through play being acknowledged as a valued component of curriculum and learning frameworks issued by countries throughout the world. In promoting a play-oriented pedagogical approach, Singapore has come up with a nuanced concept of play that involves teachers' 
intentional planning and implementation of enjoyable play activities for learning instead of adopting European or American definitions of children's play which often entails being spontaneous and child-initiated. At the same time, Singapore's official curriculum document places an emphasis on a set of broad learning goals outlining what children should know and be able to do at the end of their kindergarten education in an attempt to alleviate the problem of teachers over-teaching and parents over-preparing preschoolers to be ready for formal schooling. However, Lim and Lim (2017) opine that in order to cultivate more developmentally appropriate ECE teaching practices and free children from the unnecessary pressure of being school-ready at the end of PSE, "there needs to be more open learning among educators across kindergartens, childcare centers, and primary schools so that the notion of 'school readiness' can be demystified" (p. 201). Moving forward, apart from being driven by global trends, due consideration for developing more cogent policies and strategies grounded on a sound evidence base established from local information and data should be taken to reform kindergarten education and enhance the interface between preschool and primary school.

\section{Conclusion}

In conclusion, this article has provided some historical and current information of Singapore's journey to quality kindergarten education, which offers good learning points for countries that are also moving towards a better quality ECEC system. The descriptive overview and analysis suggest that the Singapore government has done a great deal to promote quality improvements in the preschool sector through pragmatic policymaking and strong governance frameworks. Even though much progress has been made in Singapore's quest for quality PSE since the turn of the twenty-first century, more can be done, particularly in conducting early childhood development research to better inform teacher education and professional development, and curricular and pedagogical innovations. Clearly, the government continues to stay responsive and is in fact getting into high gear to drive towards a higher quality PSE system. Just as a rising tide lifts all boats, the government is making a substantial investment of resources to develop PSE with the aim of leveling up all children through a strong start in their early learning experiences.

Acknowledgements

This paper is part of a chapter being prepared by the author for a Ph.D. degree at The University of Hong Kong. The author would like to thank her Ph.D. Supervisor, Professor Nirmala Rao for her support and thoughtful comments in guiding the preparation and revision of the manuscript. Funding support for the author's Ph.D. study is provided by the Ministry of Education, Singapore.

Competing interests

The author declares that she has no competing interests.

Publisher's Note

Springer Nature remains neutral with regard to jurisdictional claims in published maps and institutional affiliations.

Received: 12 August 2016 Accepted: 29 June 2017

Published online: 11 July 2017

References

Ang, L. Y. L. (2006). Steering debate and initiating dialogue: a review of the Singapore preschool curriculum. Contemporary Issues in Early Childhood, 7(3), 203-212. 
Ang, L. (2014). The Singapore context: A framework for a kindergarten curriculum. In L. Ang (Ed.), The early years curriculum: The UK context and beyond (pp. 113-129). London: Routledge.

Bennett, J. (2008). Early childhood education and care systems in the OECD Countries: The issue of tradition and governance. Encyclopedia on early childhood development. Montreal, Quebec: Centre of Excellence for Early Childhood Development and Strategic Knowledge Cluster on Early Child Development, pp. 1-5. http://www.child-encyclopedia.com/Pages/PDF/BennettANGxp2.pdf. Accessed 27 Nov 2015.

Bennett, J., \& Kaga, Y. (2010). The integration of early childhood systems within education. International Journal of Child Care and Education Policy, 4(1), 35-43.

Brown, S., \& Vaughan, C. (2009). Play: How it shapes the brain, opens the imagination, and invigorates the soul. New York: The Penguin Group.

Bryant, D. M., Clifford, R. M., \& Peisner, E. S. (1991). Best practices for beginners: developmental appropriateness in kindergarten. American Educational Research Journal, 28(4), 783-803.

Burgess, J., \& Fleet, A. (2009). Frameworks for change: four recurrent themes for quality in early childhood curriculum initiatives. Asia-Pacific Journal of Teacher Education, 37(1), 45-61.

Channel NewsAsia. (2014, April 3). Pre-school curriculum designed to ease transition to primary level, says MOE. http:// www.todayonline.com/singapore/pre-school-curriculum-designed-ease-transition-primary-level-saysmoe? singlepage $=$ true. Accessed 27 Nov 2015.

Chua, C. J. (1990). 3-stage primary schooling proposed. Singapore: The Straits Times.

Clark, C. M., \& Peterson, P. L. (1986). Teachers' thought process. In M. C. Wittrock (Ed.), Handbook of research on teaching (pp. 255-296). New York: Macmillan.

Davie, S. (2017, January 12). Higher demand, enrolment for kindergartens set up by MOE. Singapore: The Straits Times. http://www.straitstimes.com/singapore/education/higher-demand-enrolment-for-kindergartens-set-up-by-moe. Accessed 16 June 2017.

Department for Education. (2014). Statutory framework for the early years foundation stage. Darlington: Department for Education.

Dockett, S. (2011). The challenge of play for early childhood educators. In S. Rogers (Ed.), Rethinking play and pedagogy in early childhood education: Concepts, contexts and cultures (pp. 32-47). London: Routledge.

Ebbeck, M., \& Chan, Y. Y. Y. (2011). Instituting change in early childhood education: recent developments in Singapore. Early Childhood Education Journal, 38(6), 457-463.

Ebbeck, M., \& Gokhale, N. (2004). Child-rearing practices in a selected sample of parents with children in childcare in Singapore. Contemporary Issues in Early Childhood, 5(2), 194-206.

Eurydice, E. (2009). Early childhood education and care in Europe: Tackling social and cultural inequalities. Brussels: Eurydice.

Fullan, M. G. (2007). The new meaning of educational change (4th ed.). New York: Teachers College Press.

Gopinathan, S. (2007). Globalisation, the Singapore developmental state and education policy: a thesis revisited. Globalization Societies and Education, 5(1), 53-70.

Govt to Stop Preparatory Year Classes Next Year. (1992, March 1). London: The Sunday Times.

Goy, P. (2015, June 2). What's pre-school's effect on kids? NIE skips to the chase. Singapore: The Straits Times.

Grieshaber, S. (2010). Departures from tradition: the early years learning framework for Australia. International Journal of Child Care and Education Policy, 4(2), 33-44.

Grieshaber, S. (2016). Play and policy in early childhood education in the Asia Pacific region. Asia-Pacific Journal of Research in Early Childhood Education, 10(2), 7-28.

Growing Up with Gusto. (2009, October 30). TODAY, pp. 18.

Harms, T., Clifford, R. M., \& Cryer, D. (2005). Early childhood environment rating scale- Revised (ECERS-R). New York: Teachers College Press.

Heng, S. K. (2012, September). Keynote address by Mr Heng Swee Keat, Minister for Education, at the Ministry of Education Work Plan Seminar. Ministry of Education, Singapore. http://www.moe.gov.sg/media/speeches/2012/09/12/ keynote-address-by-mr-heng-swee-keat-at-wps-2012.php. Accessed 27 Nov 2015.

Heng, S. K. (2013). FY 2013 Committee of supply debate: 1st reply by Mr. Heng Swee Keat, Minister for Education: hope-opportunities for all. Singapore: Ministry of Education. http://www.moe.gov.sg/media/speeches/2013/03/13/fy-2013-committee-of-supply-debate-first-reply.php. Accessed 27 Nov 2015.

Hsieh, M. F. (2004). Teaching practices in Taiwan's education for young children: complexity and ambiguity of developmentally appropriate practices and/or developmentally inappropriate practices. Contemporary Issues in Early Childhood, 5(3), 309-329.

Hu, B. Y., Fan, X., Yang, Y., \& Neitzel, J. (2017). Chinese preschool teachers' knowledge and practice of teacher-child interactions: the mediating role of teachers' beliefs about children. Teaching and Teacher Education, 63, 137-147.

Kaga, Y., Barnett, S., \& Bennett, J. (2012). Integration and coordination of early childhood care and education in the republic of Korea. International Journal of Child Care and Education Policy, 6(2), 1-20.

Khoo, K. C. (2010). The shaping of childcare and preschool education in Singapore: from separatism to collaboration. International Journal of Child Care and Education Policy, 4(1), 23-34.

Kwon, Y. I. (2004). Early childhood education in Korea: discrepancy between national kindergarten curriculum and practices. Educational Review, 56(3), 297-312.

Lee, I. F., \& Tseng, C. L. (2008). Cultural conflicts of the child-centered approach to early childhood education in Taiwan. Early Years, 28(2), 183-196.

Li, H., Rao, N., \& Tse, S. K. (2012). Adapting Western pedagogies for Chinese literacy instruction: case studies of Hong Kong, Shenzhen, and Singapore preschools. Early Education and Development, 23(4), 603-621.

Li, H., Wang, X. C., \& Wong, J. M. S. (2011). Early childhood curriculum reform in China: perspectives from examining teachers' beliefs and practices in Chinese literacy teaching. Chinese Education and Society, 44(6), 5-23.

Lim, Y. F. (1989). Govt to decide on pre-primary programme. Singapore: The Straits Times.

Lim, S. M. Y. (2004). Looking at education through a Deweyan lens: how play could take shape in Singapore's preschools. Contemporary Issues in Early Childhood, 5(3), 396-401. 
Lim, M. Y. S., \& Lim, A. (2017). Governmentality of early childhood education in Singapore: Contemporary issues. In N. Rao, J. Zhou, \& J. Sun (Eds.), Early childhood education in Chinese societies (pp. 185-215). Dordrecht: Springer.

Lim, C., \& Torr, J. (2008). Teaching literacy in English language in Singaporean preschools: exploring teachers' beliefs about what works best. Contemporary Issues in Early Childhood, 9(2), 95-106.

Lim-Ratnam, C. (2013). Tensions in defining quality pre-school education: the Singapore context. Educational Review, 65(4), 416-431.

Maxwell, K. L., McWilliam, R. A., Hemmeter, M. L., Ault, M. J., \& Schuster, J. W. (2001). Predictors of developmentally appropriate classroom practices in kindergarten through third grade. Early Childhood Research Quarterly, 16(4), 431-452.

McMullen, M. B. (1999). Characteristics of teachers who talk the DAP talk and walk the DAP walk. Journal of Research in Early Childhood Education, 13(2), 216-230.

McMullen, M. B., Elicker, J., Wang, J., Erdiller, Z., Lee, S. M., Lin, C. H., et al. (2005). Comparing beliefs about appropriate practice among early childhood education and care professionals from the U.S., China, Taiwan, Korea and Turkey. Early Childhood Research Quarterly, 20(4), 451-464.

Ministry of Education (MOE). (2012a, August). Improving quality and affordability of pre- school education. Press release. Singapore: Ministry of Education. http://www.moe.gov.sg/media/press/2012/08/improving-quality-and-affordab. php. Accessed 27 Nov 2015.

Ministry of Education (MOE). (2012b). Nurturing early learners: A curriculum for kindergartens in Singapore. Ministry of Education: Republic of Singapore.

Ministry of Education (MOE). (2013). 'Educators' guide: Overview', in Ministry of Education, Nurturing early learners: A curriculum for kindergartens in Singapore. Ministry of Education: Singapore.

Ministry of Social and Family Development (MSF). (2016, September 30). One in three pre- schools now certified under Singapore Pre- school Accreditation Framework (SPARK). Press release. Singapore: Ministry of Social and Family Development (MSF). https://www.ecda.gov.sg/PressReleases/Pages/One-In-Three-Pre-Schools-Now-Certified-UnderSingapore-Pre-School-Accreditation-Framework-(SPARK).aspx.

Mohamed, A. H. H., \& Al-Qaryouti, I. A. (2016). The association between preschool teachers' beliefs and practices about developmentally appropriate practices. Early Child Development and Care, 186(12), 1972-1982.

Ng, C. M. (2016, February 29). Update on pilot MOE kindergarten project. Response to parliamentary debate. http://www. nas.gov.sg/archivesonline/data/pdfdoc/20160229002/WQ\%20-\%2029\%20Feb\%202016.pdf. Accessed 16 June 2017.

Ngiam, T. H. (1978). Lee start primary school at 5. Singapore: The Straits Times.

Nyland, B., \& Ng, J. (2016). International perspectives on early childhood curriculum changes in Singapore and Australia. European Early Childhood Education Research Journal, 24(3), 465-476.

Organisation for Economic Co-operation and Development (OECD). (2006). Starting strong Il: Early childhood education and care. Paris: OECD Publishing.

Organisation for Economic Co-operation and Development (OECD). (2012). Starting strong III:A quality toolbox for early childhood education and care. Paris: OECD Publishing.

Organisation for Economic Co-operation and Development (OECD). (2015). Starting strong IV: Monitoring quality in early childhood education and care. Paris: OECD Publishing.

Pajares, M. F. (1992). Teachers' beliefs and educational research: cleaning up a messy construct. Review of Educational Research, 62(3), 307-332.

Pan, Y. J., \& Liu, Y. (2008). A comparison of curricular practices in Chinese kindergartens: the influences of curriculum reform. International Journal of Early Childhood, 40(2), 33-48.

Pre-school Education Branch. (2008). Kindergarten curriculum guide. Singapore: Ministry of Education.

Pre-school Education Unit. (2003). Nurturing early learners: A framework for a kindergarten curriculum in Singapore. Singapore: Ministry of Education.

Puthucheary, J. (2016, April). MOE FY 2016 Committee of Supply Debate-speech by Minister of State Dr. Janil Puthucheary. Singapore: Ministry of Education. https://www.moe.gov.sg/news/speeches/moe-fy-2016-committee-of-supplydebate-speech-by-minister-of-state-dr-janil-puthucheary. Accessed 20 June 2016.

Rao, N., Ng, S. N. N., \& Pearson, E. (2010). Preschool pedagogy: A fusion of traditional Chinese beliefs and contemporary notions of appropriate practice. In C. K. K. Chan \& N. Rao (Eds.), Revisiting the Chinese learner: Changing contexts, changing education (pp. 255-279). Hong Kong: Comparative Education Research Centre, The University of Hong Kong.

Shanmugaratnam, T. (2003, January). Speech by Mr Tharman Shanmugaratnam Senior Minister of State for Trade and Industry \& Education for the official launch cum seminar of MOE's pre-school curriculum framework. Singapore: Ministry of Education. http://www.moe.gov.sg/media/speeches/2003/sp20030120.htm. Accessed 27 Nov 2015.

Sharpe, P. J. (1998). Aspects of preschool education in Singapore. Early Child Development and Care, 144(1), 129-134.

Singapore Department of Statistics. (2016). Yearbook of statistics Singapore 2016. http://www.singstat.gov.sg/docs/ default-source/default-document-library/publications/publications_and_papers/reference/yearbook_2016/ yos2016.pdf. Accessed 25 July 2016.

Spodek, B. (1988). Implicit theories of early childhood teachers: foundations for professional behavior. In B. Spodek, O. N. Saracho, \& D. L. Peters (Eds.), Professionalism and the early childhood practitioner (pp. 161-171). New York: Teachers College Press.

Sylva, K., Siraj-Blatchford, I., \& Taggart, B. (2003). Assessing quality in the early years: Early childhood environment rating scale: Extension (ECERS-E), four curricular subscales. London: Trentham Books.

Talan, T. N., \& Bloom, P. J. (2004). Program administration scale: Measuring early childhood leadership and management. New York: Teachers College Press.

Tan, C. T. (2007). Policy developments in pre-school education in Singapore: a focus on the key reforms of kindergarten education. International Journal of Child Care and Education Policy, 1(1), 35-43.

Teng, A. (2015, November 7). MOE-run pre-schools'first batch heads to P1. Singapore: The Straits Times. http://www. straitstimes.com/singapore/education/moe-run-pre-schools-first-batch-heads-to-p1. Accessed 27 Nov 2015.

Tzuo, P. W. (2007). The tension between teacher control and children's freedom in a child- centered classroom: resolving the practical dilemma through a closer look at the related theories. Early Childhood Education Journal, 35(1), 33-39. 


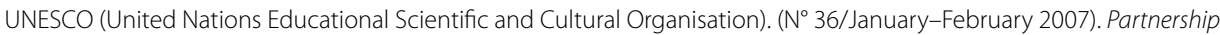
with non-public actors: Singapore's early childhood policy. Paris: UNESCO Policy Brief on Early Childhood. http://unesdoc.unesco.org/images/0014/001494/149486e.pdf. Accessed 27 Nov 2015.

Wong, A. (2000, March). Committee of supply debate FY2000, Senior Minister of State for Education, Dr Wong's responses to questions on pre-school education. Singapore: Ministry of Education. http://www.moe.gov.sg/speeches/2000/ sp14032000a_print.htm. Accessed 27 Nov 2015.

Wong, L. (2012, March). FY2012 Committee of supply debate: speech by Mr Lawrence Wong, Minister of State for Education, on better pre-schools, stronger tertiary institutions, more education opportunities for all. Singapore: Ministry of Education. http://www.moe.gov.sg/media/speeches/2012/03/08/fy2012-committee-of-supply-debate-mos-wong.php. Accessed 27 Nov 2015.

Wood, E., \& Attfield, J. (2005). Play, learning and the early childhood curriculum (2nd ed.). London: Paul Chapman.

Zulkifli, M. (2007, March). FY 2007 Committee of supply debate: 8th reply by Senior Parliamentary Secretary Mr Masagos Zulkifli on pre-school education. Singapore: Ministry of Education. https://www.moe.gov.sg/media/speeches/2007/ sp20070307h.htm. Accessed 27 Nov 2015.

Zulkifli, M. (2010, March). FY 2010 Committee of supply debate: 4th reply by Senior Parliamentary Secretary Mr Masagos Zulkifli on enhancing opportunities for all. Singapore: Ministry of Education. http://www.moe.gov.sg/media/ speeches/2010/03/10/fy-2010-committee-of-supply-de-3.php. Accessed 27 Nov 2015.

Zulkifli, M. (2011, March). FY 2011 Committee of supply debate: 4th reply by Mr Masagos Zulkifli BMM, Minister of State for Education and Home Affairs, on strengthening education for all. Singapore: Ministry of Education. http://www.moe.gov.sg/ media/speeches/2011/03/07/fy-2011-committee-of-supply-de-4.php. Accessed 27 Nov 2015.

\section{Submit your manuscript to a SpringerOpen ${ }^{\circ}$ journal and benefit from:}

- Convenient online submission

- Rigorous peer review

- Open access: articles freely available online

- High visibility within the field

- Retaining the copyright to your article

Submit your next manuscript at $\boldsymbol{\Delta}$ springeropen.com 